\title{
THE EFFECTIVENESS OF LEARNING MEDIA BASED ON THE GUIDED INQUIRY MODEL TO IMPROVE STUDENTS' SCIENCE LITERATURE SKILLS AND SCIENTIFIC ATTITUDES
}

\author{
Anita Kintan Pratiwi*, Muh Makhrus, and Muhammad Zuhdi \\ Physic Education Department, FTTE University of Mataram, Mataram, Indonesia. \\ *Email: anitakintan20@gmail.com,
}

Acceped: October 29, 2021. Approved: November 17, 2021. Published: November 17, 2021

\begin{abstract}
The study aims to determine the effectiveness of physics learning media based on the guided inquiry learning model to improve students' science literacy skills and scientific attitudes effectively and efficiently. The type of the research is a Research and Development (R\&D) which adopts the 4D model. The effectiveness obtained from the limited trial which was used to get the value of the N-gain test and the efficiency was determined from the students' responses and the results of the scientific attitude questionnaire. The results of the study based on the results of the $\mathrm{N}$-gain test obtained an average value of 0.55 with a medium category. Student responses indicated that they are not satisfied with online learning and the results of the scientific attitude response questionnaire showed that there is an increase in students' scientific attitudes. So it can be concluded that the effectiveness of the physics learning media based on the guided inquiry learning media on material of momentum and impulse is effective and efficient to improve students' scientific literacy skills and scientific attitudes.
\end{abstract}

Keywords: Learning tools, Guided Inquiry, scientific literacy, scientific attitude

\section{INTRODUCTION}

Natural science (IPA) studies natural phenomena and objects obtained by conducting observations, experiments, or trials based on the results of human observations in the form of facts, rules, laws, principles, and theories related to nature. Makhrus et al. [1] proposed that science does not only consist of knowledge that is isolated from one to another but a series of knowledge that is systematically organized. Science essentially underlies the rapid development of 21st century technology. Technological developments require human resources to have the skills demanded by the $21^{\text {st }}$ century. Makhrus et al. [2] suggested that the implementation of Curriculum of 2013 is expected to be implemented in $21^{\text {st }}$ century learning which reflects four things, namely critical thinking and problem solving, creativity and innovation, communication and collaboration. Based on this opinion, it is very important for students have the skills that the $21^{\text {st }}$ century demands.

Physics learning is quite different compared to other subjects, this is because not all learning materials can be delivered directly. According to Eerniati [3] one of the approaches which can improve students' science literacy is implementing guided inquiry in the learning process. The learning process based on the guided inquiry gives students opportunity to be directly taking part in the process so that it can be meaningful for students. The main characteristic of guided inquiry is that students are directed to seek and find the learning consent independently, critically, and logically. Students will eventually develop the skills themselves. Inquiry learning gradually changes the learning pattern from inactive into active and critical learning.
Based on the OECD data [4], Indonesia ranks low in reading, mathematics, and science literacy respectively, 61,57 , and 60 out of 65 countries, Ministry of Education and Culture [5]. Based on the case, governments have taken real actions in overcoming the challenges of $21^{\text {st }}$ century by making policy related to the curriculum. Makhrus et al [2], the learning process in Curriculum of 2013 refers to scientific process by the means to educate students from an early age about the importance of science literacy. The learning process will be a lot more meaningful if students can find the learning concepts independently through the scientific process in which requires them to implement science literacy.

Science literacy is defined as the capacity to apply the scientific knowledge, identify the questions, and draw conclusions based on the facts and data to have a good understanding about the nature and make decisions of the changes which occurred because of human activities OECD [4]. Students' low learning outcome due to their lack of science literacy causes them not having a good understanding of Physics material. Assessment of scientific attitudes in learning process is important as references to picture students' capability in the learning process of Physics.

Based on the observations conducted at SMAN 2 Sumbawa Besar, in the learning process, many of the students can't solve Physics questions. The kind of learning process does not allow students to grow independently in building their own knowledge. Thus affects the students' science literacy and scientific attitudes in which are not sharpened during the process and they eventually find the questions harder than the given examples during the learning process. The most effective 
learning for students is obtained through the learning method which allows student to learn by teaching in sense that teachers teach the students and the students can do the teaching either to the fellow students or the teachers in certain conditions, Suyuno et al [6]. Students often draw conclusion that Physics is difficult and filled by counting material. This is in line with Rokhmat [7] that teachers have tendency to lead students to learn a number of equations (formulas) in related cases.

Based on the problems, there is a need of the learning model which can connect the students' previous knowledge with new information so that it can improve students' science literacy and scientific attitudes. It can be done by applying a guided inquiry model. Guided inquiry model can grow and develop scientific attitudes through the application of Science which is carried out by planning, experimenting, researching, observing, analyzing, and drawing conclusion in order to improve students' scientific attitudes. The learning process will be more meaningful if students can find the learning concepts independently by applying the scientific process and science literacy in the learning process.

Learning begins with a scientific problem, followed by stating a hypothesis and conducting investigation to solve the problems by literature search and laboratory activity. The understanding of the material gained from the process of problem solving is used to draw conclusion in everyday life. This explains the meaning of guided inquiry learning based on the scientific literacy. The purpose of the study is to describe the implementation of guided inquiry learning model to improve science literacy and scientific attitudes.

\section{RESEARCH METHODS}

The method used is a Research and Development (R\&D) method. Sugiyono [8] defines research development as a learning method which is used to produce a research product and evaluate the effectiveness of the product itself. The subject of the study was X MIPA students of SMAN 2 Sumbawa Besar in academic year of 2020/2021 with a total of 20 students. The study adopts the 4D model which consists of the following steps:

\section{Define}

The purpose of the step is to set and define the learning conditions by analyzing the purpose of material limitations which is developed in the learning media. This step was carried out by conducting observation and interview.

\section{Design}

The purpose of the design step is to get the form of learning media. The developed learning media based on guided inquiry model with learning materials of momentum and impulse. The result of this step was learning media consisted of syllabus, lesson plan, students' worksheet, and evaluation instrument of science literacy skill and scientific attitudes.

Develop

The purpose of the step is to produce learning media in the form of syllabus, lesson plan, students' worksheet and evaluation instrument. The step was carried out by conducting limited trial to yield the improvement data of students' science literacy skills and scientific attitudes. The improvement of science literacy skill and scientific attitudes could be determined by conducting analysis of learning effectiveness which obtained by calculating the activity improvement and students' learning outcomes of Physics through the calculation of normalization gain $(N$-gain $)$ with the following formula Hake et al [9]

Table 1. Learning implementation criteria

\begin{tabular}{cl}
\hline \multicolumn{1}{c}{ Interval } & Criteria \\
\hline$g>0,70$ & High \\
$0,30 \leq g \geq 0,70$ & Moderate \\
$g<0,3$ & Low \\
\hline
\end{tabular}

Source (Hake, 1998)

The step was followed by analyzing students' responses to determine the students' scientific attitudes during the learning process. The data of students' responses to the learning media in the form of questionnaire with the scale range of 1 to 4 . Scale of 3 and 4 refer to positive respond and scale of 1 and 2 refer to negative respond Hobri [10].

Table 2. Category of response percentage calculation results

\begin{tabular}{cl}
\hline Score & \multicolumn{1}{c}{ Category } \\
\hline $81 \%-100 \%$ & Very good \\
$61 \%-80 \%$ & Good \\
$41 \%-60 \%$ & Pretty Good \\
$21 \%-40 \%$ & Not Good \\
$\leq 20 \%$ & Not very good \\
\hline
\end{tabular}

\section{Disseminate}

The purpose of the step is to disseminate the research product in the form of Physics learning media based on the guided inquiry model which was developed. The disseminate step was carried out by creating scientific paper of the research which was disseminated in the form of $e$-journal.

\section{RESULTS AND DISCUSSION}

The purpose of the study is to describe students' science literacy and scientific attitudes during and after the learning process. Observation and interview were conducted at an early step of 
the study. The results of observation at SMAN 2 Sumbawa Besar found that students still experience many problems during the learning process. Teacher-centered learning process has been one of obstacles students' experienced. This condition does not allow them to improve their science literacy and scientific attitudes and literally got no skill in problem solving during the learning process. The results of interviews with Physics teacher stated that limited time and inadequate facilities were the main reasons teachers couldn't implement guided inquiry model.

The learning material and specifications of learning purposes were determined based on the results of observations and interviews. A preliminary analysis on the learning media that will be used on the learning material of Momentum and Impulse were designed. The results of the analysis consisted of syllabus, lesson plans, worksheets, and evaluation instrument of students' science literacy and scientific attitudes. Furthermore, an expert trial was conducted to validate the developed instruments in the study. Validity test was carried out by six valuators consist of three lecturers and three teachers. The results were valid with minor revision.

The next step was conducting limited trial to students of X MIPA 2 with a total of 20 students. The tests for limited trial is in the form of pre-test and post-test to determine students' science literacy and scientific attitudes. The tests' questions is arranged in the form of multiple choices consisting of 25 items which contain indicators of science literacy and scientific attitudes. The effectiveness of the instruments was showed by the results of $N$ gain, while the efficiency of the instruments was showed by students' responses during the learning activities. The instruments effectiveness was determined by the data analysis of students' science literacy and scientific attitudes after implementing guided inquiry model and limited trial. Limited trial was conducted to 20 students. The improvement of science literacy and scientific attitudes were analyzed using $\mathrm{N}$-gain calculation. The results of the analysis are showed in the following Table 3.
$\mathrm{N}$-gain was used to measure the skill improvements of science literacy and the results of cognitive learning before and after the learning process take place, in which there were score differences, the average scores were respectively 65.8 and 84.5. The results indicated that there is an improvement of science literacy and scientific attitudes, although the skills were not significantly improving. Separately, there were 5 students in the category of high, 12 students were in the category of moderate, while 3 students were in the category of low. The percentage of each category was respectively $25 \%, 60 \%$, and $15 \%$. The students' responses showed that students were interesting in participating during the process. N-gain test obtained the average score of 0.55 in the category of moderate.

The result is in line with the study conducted previously by Cindy et Cindy et al [11], Anam [12], Brickman [13] \& Elsy Zuriyani [14] that the science implementation of guided inquiry model can grow and develop students' science literacy and scientific attitudes by the steps of planning, experimenting, researching, observing, analyzing and drawing conclusion. The process will give a meaningful learning to students if they are given the opportunity to find the learning concept through the scientific process implemented during the learning process. Based on the results, it can be concluded that the Physics learning media based on guided inquiry model is effective and efficient to improve students' science literacy and scientific attitudes.

In the following step, students' completed the questionnaire in the Google form. The data analysis was determined by the scores of each question, the data was calculated and interpreted into percentage. The closure the value to $100 \%$, the more students' responses show a good scientific attitude. The questionnaires which consist of before and after the treatment were conducted to 20 students. According to Hobri [10], responses' percentage was calculated using equation 2 . The result of students' scientific attitudes responses before after the treatment is presented in the following table 4 and table 5 .

Table 3. The results of $\mathrm{N}$-gain

\begin{tabular}{lllllr}
\hline$\overline{\boldsymbol{x}}$ pretest & $\overline{\boldsymbol{x}}$ posttest & $\overline{\boldsymbol{x}}$ pretest $-\overline{\boldsymbol{x}}$ posttest & $100-\overline{\boldsymbol{x}}$ pretest & N-gain Score $(\mathrm{g})$ & Criteria \\
\hline 65,8 & 84,45 & 18,65 & 34,2 & 0,55 & Moderate \\
\hline
\end{tabular}

Table 4 . The results of calculation criteria analysis and $\mathrm{N}$-gain percentage

\begin{tabular}{clcc}
\hline N-gain Score $(\mathrm{g})$ & Criteria & Number of students & Persentage \\
\hline$g \geq 0,70$ & High & 5 & $25 \%$ \\
$0,30 \leq g \geq 0,70$ & Moderate & 12 & $60 \%$ \\
$g \leq 0,70$ & Low & 3 & $15 \%$ \\
\hline
\end{tabular}

Table 5. The results of before after the 


\begin{tabular}{lll}
\hline Treatment & Percentage & Criteria \\
\hline Before & $86.00 \%$ & Very good \\
After & $89.00 \%$ & Very good \\
\hline
\end{tabular}

Based on the Table above, there is an improvement of scientific attitudes between before and after treatment in which there is $3 \%$ of improvement from $86.00 \%$ to $89.00 \%$ in the category of very good. Students can improve their scientific attitudes because scientific attitude itself is defined as attitude to accept other people's opinion properly and know no discouragement with perseverance and openness [15-16]. Students' active participation, both mentally and physically in the laboratory activities shapes an action pattern that will always based on the scientific manners and matters.

\section{CONCLUSION}

Based on the result and discussion, it can concluded that the implementation of learning media based on guided inquiry model can improve students' science literacy and scientific attitudes, in the category of moderate based on the standard calculation of $\mathrm{N}$-gain. The questionnaire to observe students' responses using Google form was conducted to determine whether or not there is improvement. The data analysis showed that the students' responses before and after treatment were respectively $86.00 \%$ and $89.00 \%$, both in the category of very good. The results showed that the learning media based on the guided inquiry learning can effectively improve students' science literacy skills and scientific attitudes during the learning process in the material of Momentum and Impulse.

\section{REFERENCES}

[1] Makhrus, M., \& Hadiprayitno, G. (2012). Penerapan Perangkat Pembelajaran Fisika Berorientasi Pembelajaran IPA Terpadu Tipe Connected. Jurnal Pendidikan dan Pembelajaran, 19(2), 237-242.

[2] Makhrus, M., Harjono, A., Syukur, A., Bahri, S \& Muntari. (2019). Analisis Rencana Pelaksanaan Pembelajaran (RPP) Terhadap Kesiapan Guru Sebagai Role Model Keterampilan Abad 21 pada Pembelajaran IPA SMP. Jurnal Penelitian Pendidikan IPA, 5(1), 66-72.

[3] Erniati, L. (2010). Membangun VOIP Secara Sederhana. Jurnal Kependidikan, 20 (2): 187201.

[4] Organisation for Economic Co-operation and Development. (2003). The PISA 2003 Assessment Framework. Paris: OECD.
[5] Kemendikbud. (2013). Lampiran Permendikbud Nomor 81A Tahun 2013 Tentang Implementasi Kurikulum Pedoman Umum Pembelajaran. Jakarta: Kementerian Pendidikan dan Kebudayaan RI.

[6] Suyono \& Harianto. (2011). Belajar dan Pembelajaran. Surabaya: Remaja Rosdakarya.

[7] Rokhmat, J. (2015). Penerapan Pendekatan Berpikir Kausalitik Ber-scaffolding dalam Meningkatkan KPM Hukum Newton tentang Gerak. Prosiding Seminar Nasional Fisika. Mataram: Universitas Mataram.

[8] Sugiyono, S. (2014). Metode Penelitian Pendidikan Pendekatan Kuantitatif, Kualitatif, dan R\&D. Bandung: Alfabeta.

[9] Hake, R. R. (1998). Interactive-engagement vs traditional methods: A six-thousandstudent survey of mechanics test data for introductory physics courses. American Journal of Physics, 66 (1), 64-74.

[10] Hobri. (2010). Metodologi Penelitian Pengembangan. [Aplikasi Pada Penelitian Pendidikan Matematika]. Pena Salsabila. Jember.

[11] Cindy, R. G., Golan, R. A., \& Clarck C. (2013). Scaffolding and Achievment in Problem Based and Inquiry Learning: A Reponse to Krischner, Sweller and Clarck. Journal of Education Psychologist. 42(2), 99107.

[12] Hasanah, J., Jamaludin, J., \& Prayitno, G. H. (2019). Bahan Ajar IPA Berbasis Inkuiri Terstruktur Untuk Meningkatkan Literasi Sains Peserta Didik SMP. Jurnal Pijar MIPA, 14(2), 18-24.

[13] Brickman, B. (2016). Effect of InquiryBased Learning on Student's Science Literacy Skills and Confidence. International Journal for The Scholarship of Teaching and Learning, 3(2). 234-244.

[14] Anam, Khoirul. (2015). Pembelajaran Berbasis Inkuiri Model dan Aplikasi. Yogyakarta: Pustaka Pelajar.

[15] Qomaliyah, E. N., Sukib, S., \& Loka, I. N. (2017). Pengaruh model pembelajaran inkuiri terbimbing berbasis literasi sains terhadap hasil belajar materi pokok larutan penyangga. Jurnal Pijar Mipa, 11(2).

[16] Haerani, S. A. S., Setiadi, D., \& Rasmi, D. A. C. (2020). Pengaruh Model Inkuiri Bebas Terhadap Kemampuan Literasi Sains. J. Pijar MIPA, 15(2), 140-144. 